Cahiers $d u$ MONDE RUSSE

\section{Cahiers du monde russe}

Russie - Empire russe - Union soviétique et États indépendants

52/2-3 | 2011

L'URSS et la Seconde Guerre mondiale

\title{
Soviet policy toward Japan during World War II
}

La politique soviétique envers le Japon pendant la Seconde Guerre mondiale

\section{Tsuyoshi Hasegawa}

\section{CpenEdition \\ Journals}

Electronic version

URL: https://journals.openedition.org/monderusse/9333

DOI: 10.4000/monderusse.9333

ISSN: $1777-5388$

\section{Publisher}

Éditions de l'EHESS

\section{Printed version}

Date of publication: 15 November 2011

Number of pages: $245-271$

ISBN: 978-2-7132-2352-5

ISSN: $1252-6576$

\section{Electronic reference}

Tsuyoshi Hasegawa, "Soviet policy toward Japan during World War II", Cahiers du monde russe [Online], 52/2-3 | 2011, Online since 12 September 2014, connection on 02 September 2022. URL: http://journals.openedition.org/monderusse/9333; DOl: https://doi.org/10.4000/monderusse. 9333

This text was automatically generated on 2 September 2022.

All rights reserved 


\title{
Soviet policy toward Japan during World War II
}

\author{
La politique soviétique envers le Japon pendant la Seconde Guerre mondiale
}

Tsuyoshi Hasegawa

1 The Soviet Union fought the war against Japan in Manchuria, Korea, Sakhalin, and the Kurils from August 9 through September 5, 1945. ${ }^{1}$ It is important to incorporate the Far Eastern theater into the general description of the Soviet role in World War II for three reasons. First, during the war Stalin always considered the Far East one of the important factors in his comprehensive strategy in the war. Second, the war that the Soviet Union fought in Asia also contributes to the discussion on whether Stalin and Soviet policy during World War II were motivated by the realist approach or by ideology. Third, the end of the Pacific War marked the beginning of the nuclear age, and therefore, how Stalin reacted to the American use of the atomic bomb had important implications for the subsequent development of the relationship between nuclear weapons and the Cold War. ${ }^{2}$

This paper attempts to examine the objectives of Soviet policy in the war against Japan. I argue that the primary goals of the Soviet Union from the Yalta Conference to the entry into the war were to enter the war so that it could obtain the war trophies promised at Yalta, and further that once the Soviet Union managed to enter the war, the Soviets were determined to physically occupy these territories. By skillfully combining diplomacy and military operations, Stalin managed to achieve his goals. This is not to say that Stalin pursued his policy without any mistakes. In fact, he misjudged the U.S. fears of the Soviet role in the Pacific War, and he was completely outwitted by Truman about the Potsdam Proclamation. Nevertheless, he was aided by Japan's reliance on Soviet neutrality. In the end, the Soviet entry into the war played a more crucial role in Japan's decision to surrender than the U.S. atomic bombing of Hiroshima and Nagasaki. ${ }^{3}$ Stalin achieved his goals in the war against Japan, but in the long run, the Soviet entry into the war and the occupation of the Kurils instilled profound enmity among the Japanese against the Soviet Union, making it exceedingly difficult for the Soviet Union to achieve rapprochement with Japan. 


\section{Soviet policies in Europe and the Far East}

3 It is well to remember that the Soviet Union faced threats from two directions prior to the outbreak of World War II, from Nazi Germany and from Japan. ${ }^{4}$ To counter the threat from Japan, the Soviet Union employed diplomacy and military operations. In reaction to the Manchurian Incident, the Soviet government initially adopted an appeasement policy, unsuccessfully offering to conclude a non-aggression pact with the Japanese, and selling the Chinese Eastern Railway (CER) to Japan in 1935. After the outbreak of the Sino-Japanese War in 1937, the Soviets concluded a non-aggression pact with China and began to provide military aid in order to sink Japan deeper in the quagmire of their war with China. Militarily, the USSR created the Far Eastern Military District, doubletracked the Siberian Railroad, established the Pacific Fleet, increased the number of troops deployed in the Far East, and engaged in successful military operations against the Japanese troops in the Lake Khasan incident of 1938, and the Nomonhan war of 1939. ${ }^{5}$

4 After the outbreak of World War II in Europe, the Soviet government concluded the Neutrality Pact with Japan in April 1941, to avoid a two-front war. When the Germans attacked the Soviet Union on June 22, Stalin ordered the Far Eastern front not to take any actions that might provoke Japan's attack, while maintaining sizable forces in the Far East. It was only when Stalin was reassured by intelligence sources that Japan was not likely to attack the Soviet Union, that he moved the best divisions in the Far East to bolster the defense of Moscow. ${ }^{6}$

5 Once the first imminent threat for survival of the Soviet Union receded in December, 1941, Stalin revealed his intention to join the war against Japan in his conversations with British Foreign Secretary Anthony Eden, although he rejected Eden's request to join the war immediately. The Soviet Union was bound by the Neutrality Pact, Stalin explained, and as long as the nation had to devote all its energy to fight the Germans, it could not wage war on two fronts.?

6 After the victory of the battle of Stalingrad, however, Stalin began seriously making preparations for the war against Japan. He ordered the NKVD to construct a new railway line to connect Komsomolsk-na-Amure to Sovetskaia Gavan' on the Pacific Coast. At the Foreign Ministers Conference in Moscow and at the Teheran Conference in October 1943, he pledged to enter the war against Japan after the capitulation of Germany, a promise that was made to extract Allied agreement to open a second front in Europe. He intended to wage war against Japan for geopolitical interests, regardless of the Allied position, but he managed to sell this demand as if it was his concession to the Allies. At the conference, he made it clear that he would make known in due course his "desiderata" for Soviet entry into the Pacific War. ${ }^{8}$

7 Meanwhile, Stalin requested from his foreign policy experts their position papers on Soviet policy toward Japan. Both the Deputy Commissar of Foreign Affairs, Ivan Maiskii, in January and the Ambassador to Tokyo, Iakov Malik, in June, 1944, in separate memoranda advocated obtaining Soviet borders that would assure the future security of the Soviet Union, specifically insisting on regaining southern Sakhalin and the Kurils. ${ }^{9}$ Both justified these demands in terms of Soviet security, not on the basis of historical legitimacy or any ideological principle. But Maiskii and Malik assumed that these demands should be met by the Allies in a peace conference after the war without the Soviet Union participating in the war. Stalin disagreed. Skeptical about the Allies' goodwill to honor their commitment to the Soviet demands, Stalin was determined to 
occupy these territories by military means. War against Japan was a necessary prerequisite to fulfill his goal.

8 In the summer of 1944, Stalin told Marshal Aleksandr Vasilevskii, Commander of the Belorussian front, about his intention to appoint him commander of the Far Eastern front to oversee Soviet preparations for the war against Japan. In September, in strict secrecy, Stalin ordered the General Staff to draw up estimates for the concentration and logistical support of troops in the Far East in the war against Japan. The General Staff completed the estimates at the beginning of October. ${ }^{10}$

In December, Stalin for the first time revealed his "desiderata" to Harriman. He brought out a map and said that southern Sakhalin and the Kurils should be returned to the Soviet Union. Stalin then drew a line around the southern part of the Liaotung Peninsula including Dairen and Port Arthur, and said that the Soviet Union wished to secure the lease for these ports again. In addition, he also wished to obtain the lease for the CER and the Southern Manchurian Railway, and demanded recognition of the status quo in Outer Mongolia. ${ }^{11} \mathrm{He}$ was determined to acquire everything on this list at the Yalta Conference.

\section{Yalta Conference, February 1945}

10 By concluding the Yalta secret agreement with Roosevelt and Churchill at the Yalta Conference Stalin managed to gain the concessions he had revealed to Harriman in return for his pledge to enter the war against Japan three months after the German capitulation. ${ }^{12}$ With regard to subsequent Soviet policy toward Japan, the following factors should be mentioned.

11 First, the Yalta secret agreement was a masterpiece of Stalin's diplomatic maneuvering. The article that dealt with the Kurils was separated from the article that stipulated the restoration of Russia's former rights "violated by the treacherous attack of Japan in 1904." By insisting that this independent article on the Kurils was as important as the others and carefully using the expression, "handed over," rather than "restored," Stalin precluded the possibility that the Kurils would be taken away later as a violation of the Atlantic Charter and the Cairo Declaration. Moreover, having Roosevelt and Churchill pledge that these claims "shall be unquestionably fulfilled after Japan has been defeated," he made doubly sure that these promises would not be ignored. ${ }^{13}$

Second, in order for Stalin to gain these war trophies, he had to fulfill two important conditions: participation in the war and agreement with the Chinese government on the Yalta terms. Otherwise, the Allies might renege on their promises at the peace conference. Thus, it was imperative for him not only to enter the war, but to prevent the war from ending before the Soviets joined it. Third, Stalin's diplomatic success was based on the continuation of his previous tactical maneuvers. Relying on America's need to secure Soviet participation in the war against Japan, he presented his real objectives as if they were concessions to the United States.

\section{Abrogation of the Neutrality Pact}

13 On April 5, Molotov informed the Japanese Ambassador to Moscow Sato Naotake that the Soviet government had no intention to renew the Neutrality Pact. To Sato's question about whether the Soviet government was annulling the pact forthwith or whether it 
took the position that the pact was still in force until the end of its original five-year term in April 1946, Molotov stated that the pact would remain in force until it expired. Reconfirming the validity of the Neutrality Pact, while in secret preparing the war against Japan, left unresolved the problem of how to justify the violation of the pact once the Soviets went to war against Japan. ${ }^{14}$

Why did the Soviet Union renounce the Neutrality Pact? The first explanation is that unless the Soviet government notified the Japanese, the pact would have been renewed automatically for another five years. ${ }^{15}$ Obviously, Stalin did not wish his countrymen to compare an eventual Soviet violation of the Neutrality Pact with the German violation of the Non-Aggression (Molotov-Ribbentrop) Pact.

The more compelling reason was that this was intended as a message to the United States that the Soviet Union was preparing to honor its commitment to enter the war against Japan after Germany's capitulation at the time when the relationship with the US was becoming increasingly contentious. He had reasonable expectations that the renunciation of the Pact would not provoke Japan's attack, since he received intelligence reports from Japan that reassured him that Japan would continue to seek Soviet neutrality. ${ }^{16}$ Nevertheless, before the Soviet government renounced the Pact, Stalin ordered the military leaders in the Far East to place Soviet troops on alert for possible Japanese attacks, to strengthen the protection of the railways, and to reinforce the defense of major cities including Vladivostok and Khabarovsk. ${ }^{17}$

\section{May-June 1945: Stalin-Hopkins and Hirota-Malik meetings}

The growing tension between the United States and the Soviet Union over Poland and the unannounced suspension of Lend Lease prompted Truman to send his special envoy, Harry Hopkins, to Moscow to iron out differences. The Far Eastern question was also an important issue at this meeting. To Hopkins' question of when the Soviet Union would enter the war, Stalin replied that the Soviet Army would be "in sufficient preparedness" by August 8. Stalin promised, not that the Soviets would enter the war precisely on August 8, but that preparations would be completed by that date. Later, Stalin remarked that the opening of operations would depend on the weather, since the autumn fog could make the campaign difficult. ${ }^{18}$

17 Stalin raised the possibility of discussing "the zone of operations for the armies and zones of occupation of Japan." Hopkins cabled to Truman: "The Marshal expected that Russia will share in the actual occupation of Japan and wants an agreement with the British and us as to occupation zones." ${ }^{19}$ Hopkins' acceptance of this proposal may have whetted Stalin's appetite and this may have led to his demand during the Soviet Hokkaido-Kuril operations for both a Soviet occupation zone on the northern half of Hokkaido and a Soviet occupation sector in Tokyo. ${ }^{20}$ The most important point at the Stalin-Hopkins conference was Hopkin's offer to include concrete proposals for Japan's surrender on the agenda of the forthcoming Big-Three conference in Potsdam. ${ }^{21}$ This would give Stalin a justification to enter the war against Japan in violation of the Neutrality Pact.

18 As the emperor and the policymakers in Japan became aware of the impending defeat of the Battle of Okinawa, they decided to seek rapprochement with the Soviet Union to exit 
from the war. To achieve this goal, the Japanese government entrusted former prime minister and foreign minister Hirota Koki to contact Ambassador Malik on June 7 in an unofficial capacity. During a series of meetings with Malik in June Hirota sounded out the possibility of concluding an alliance or a non-aggression pact, or at least the renewal of the Neutrality Pact. Japan's ill-advised move fell right into the Soviet trap to prolong the war. Molotov instructed Malik to neither agree on specific conditions nor cut off negotiations. As it turned out, the terms Japan offered to renew the Neutrality Pact were less generous than the written promise that Stalin had obtained from Roosevelt and Churchill at Yalta. And Malik, as instructed, set a snail's pace for negotiations by sending the Japanese proposals through the diplomatic pouch..$^{22}$

\section{The Politburo decides to go to war}

19 Stalin summoned a combined meeting of top leaders of the Politburo, the government, and the military on June 26 and 27. This meeting decided to launch an all-out offensive against Japanese forces in Manchuria in August. The General Staff's recommendation that three fronts simultaneously move toward the center of Manchuria met with final approval. ${ }^{23}$ War against Japan was no longer a secret confined to Stalin and a small circle of his advisers: it became the official policy of the Soviet government.

At this conference the geographical parameters of the military operation were discussed. The major objective of the Soviet military operation was to secure all the territories promised by the Yalta Agreement, including Manchuria, southern Sakhalin, and the Kuril Islands. The occupation of northern Korea was considered essential to cut off the escape route of the Japanese forces. Opinions were divided, however, on the advisability of the Hokkaido operation. Without the occupation of Hokkaido, the Soviets could not secure control of the Soya Strait and the Kurils. Marshal K.A. Meretskov thus proposed that they occupy the island. This measure was supported by Nikita Khrushchev, but Nikolai Voznesenskii, Molotov, and Marshal Georgii Zhukov opposed the operation as too risky, even likely to provoke counteraction from American forces. Stalin asked Zhukov how many additional divisions would be needed to carry out this operation. The marshal answered at least four. Stalin said nothing further. The question of Hokkaido remained undecided. ${ }^{24}$

21 The following day on June 28 Stalin issued three directives, the first to the commanderin-chief of the Far Eastern Front to complete all the preparations for the attack by August 1; the second to the commanders of the troops of the Maritime groups to complete the preparations for attack by July 25; and the third to the commander of the Transbaikal front to complete preparations by July $25 . .^{25}$ These orders did not set the precise date of attack, which would most likely be decided later in consultation with the commanders in the Far East. ${ }^{26}$ The gigantic war machine in the Far East had been set in motion.

\section{Pre-Potsdam: Japanese-Soviet and Sino-Soviet negotiations}

Only after the USSR had made the final decision to wage war against Japan, did the Japanese government abandon its futile attempt through Hirota to conclude an 
agreement with the Soviets, and requested Soviet mediation to terminate the war. On July 12, Foreign Minister Togo sent a telegram to Ambassador Sato, instructing the ambassador to see Molotov immediately to present the emperor's message requesting Moscow's mediation to terminate the war. Togo stated that it was the emperor's wish to end the war, but made it clear that so long as the Allies demanded unconditional surrender, Japan had no choice but to fight to the last man. ${ }^{27}$ Molotov, however, refused to meet Sato before his departure for Potsdam.

Molotov instructed his deputy, Solomon Lozovskii, not to reject this request outright, but to encourage Sato to clarify the ambiguities in Togo's telegram with regard to whom it was addressed. Clearly, the Soviets intended to keep Japan waiting to buy more time. Stalin was, however, keenly aware that Japan's surrender was imminent. Consumed by the fear that the war might end before the Soviet Union could join it, even before the Potsdam Conference began, Stalin called Vasilevskii, and asked him if it would be possible to move up the date of attack by ten days from the August 11 set by the Stavka. Vasilevskii answered that "the concentration of the troops and the transportation of essential war supplies would not permit such a revision" of the attack schedule. Stalin, for the time being, accepted Vasilevskii's cautious judgment. ${ }^{28}$

Before entering the war, Stalin had to secure Chiang Kai-shek's consent to the Yalta provisions. The provisions of the Yalta secret agreement grossly violated the sovereign rights of the Chinese government. Although Chiang Kai-shek was informed about the Yalta secret agreement a few weeks after the conference, he was not formally told of its specific provisions regarding Chinese territory until June $15 .{ }^{29}$ Stalin and the Chinese Foreign Minister T.V. Soong began negotiations on July 2. Soong was adamant about China's rights with respect to Outer Mongolia and railways and ports in Manchuria. While China insisted that it could not make concessions on these issues involving sovereignty, to Stalin these represented the indispensable acquisitions on which future Soviet security would depend. The unsuccessful negotiations were broken off when Stalin and Molotov left Moscow for Potsdam and Soong returned to Chongqing for further instructions..$^{30}$

\section{Potsdam Conference}

\section{Settings}

Stalin came to Potsdam, assuming that the United States still needed the Soviet entry into the war. He also counted on Hopkins's assurance that the United States would place the question of a joint ultimatum to Japan on the agenda. Also, Stalin hoped that the United States would exert pressure on the Chinese to accept the Yalta provisions. Thus, Stalin expected Truman, who, he assumed, was as eager as Roosevelt to invite the Soviets to join the war, to help resolve these two obstacles.

Before the Potsdam Conference, Truman had faced two irreconcilable dilemmas. The first was how to deal with the Soviets. Truman and his new secretary of State, James Byrnes, began to worry about the implications of the Soviet entry into the war against Japan, which would inevitably expand Soviet influence in Asia. If he could avoid it, Truman would prefer to end the war before the Soviets entered it. Nevertheless, his military advisers argued that even if Soviet participation in the war was no longer necessary to win the war, it would still hasten Japan's surrender, thereby saving American lives. 
Truman faced another dilemma over unconditional surrender. Not only was unconditional surrender Roosevelt's legacy, but this demand was supported by the overwhelming majority of the American people. Truman felt that it was necessary to avenge the humiliation suffered by Japan's attack on Pearl Harbor by bringing Japan to its knees by imposing unconditional surrender. But many influential advisers such as Secretary of War Henry Stimson, Under Secretary of State Joseph Grew, and Navy Secretary James Forrestal came to advocate revision of the surrender conditions in such a way as to allow the Japanese to maintain the monarchical system under the present dynasty. This concession, they argued, would strengthen moderate elements that surrounded the emperor and induce them to seek early surrender.

The situation suddenly changed on July 16 when the United States succeeded in exploding the first atomic bomb in Alamogordo in New Mexico. With this powerful new weapon, the US could imagine forcing the Japanese surrender without relying on Soviet participation in the war. It made it possible for Truman to stick to the unconditional surrender demand. With the detonation of the atomic bomb in New Mexico, the major goal of Truman and Byrnes now shifted to securing Japan's surrender before the Soviets could enter the war. ${ }^{31}$

\section{Stalin-Truman meetings: July 17 and July 18}

At the first Stalin-Truman meeting on July 17 prior to the opening of the conference, Stalin told Truman that the Soviet Union was ready to enter the war "by the middle of August," but he said that prior to the Soviet entry into the war he would need to reach an agreement with the Chinese. Although the Soviet record of this meeting makes us believe that it was Truman who solicited the Soviet entry into the war and requested information about the Sino-Soviet negotiations, the American record makes it clear that it was Stalin, who without Truman's prodding volunteered to express his intention to enter the war, and brought up the issue of the Sino-Soviet negotiations. ${ }^{32}$

Differences between the two versions of this meeting speak volumes about the different expectations each leader had of the other. Stalin felt that Truman should feel gratitude for his commitment to enter the war "by the middle of August." For this pledge to enter the war, Stalin expected Truman to reward him by putting pressure on the Chinese to come to an agreement with the USSR. But Truman was ambiguous about the Soviet entry into the war. In his Potsdam diary, Truman wrote: "He'll be in the Jap War on August $15^{\text {th }}$. Fini Japs when that comes about." This passage, often taken by historians as the convincing evidence that Truman welcomed the Soviet entry into the war must be balanced by the passage that preceded it: "I asked if he had the agenda for the meeting. He said he had and that he had some more questions to present. I told him to fire away. He did and it is dynamite - but I have some dynamite too which I'm not exploding now." ${ }^{33}$ Truman and Byrnes were working out a "timetable" to force Japan's surrender. They wished to avoid Soviet entry into the war, and they were determined to use the atomic bomb for that purpose. With Stalin's reference to the date of Soviet entry into the war either "by the middle of August" or "in the middle of August," Truman believed that the Soviets would enter the war on August $15 .^{34}$

31 Stalin wanted the U.S. pressure on China to come to an agreement by volunteering the information that the Soviets were ready to enter the war. But he was disappointed, because although Byrnes committed himself to the Yalta secret agreement, he warned 
that the United States would not support any provisions that went beyond the Yalta provisions. Furthermore, Truman and Byrnes insisted on the free port status of Dairen. ${ }^{35}$ Clearly, the Americans were not playing the game as Stalin had hoped.

On July 18, when Truman paid a return visit to Stalin's villa, Stalin revealed the information that the Japanese had asked Moscow to mediate in ending the war. He revealed to Truman Ambassador Sato's note requesting Soviet mediation to terminate the war. According to the American record, "Stalin pointed out that the Soviet Union was not at war with Japan and that it might be desirable to lull the Japanese to sleep, and possibly a general and unspecific answer might be returned, pointing out that the exact character of the proposed Konye [sic] mission was not clear." Truman agreed. ${ }^{36}$ Stalin was eager to prolong the war until all the preparations for his attack were completed, while Truman was also interested in prolonging the war only until the atomic bomb could be dropped to shock the Japanese into surrender.

\section{Truman tells Stalin half-truth about the atomic bomb}

General Leslie Groves' detailed report of the atomic bomb test in Alamogordo reached Truman on July 21 . This was the "dynamite" Truman had eagerly been waiting for. With the atomic bomb, he was confident that the United States could unilaterally force Japan to surrender without the Soviet Union. It became important, therefore, to exclude Stalin from the joint ultimatum to Japan. The atomic bomb also made it possible, he believed, to dictate unconditional surrender to Japan. ${ }^{37}$

During a recess of the Potsdam Conference on July 24, Truman approached Stalin and casually revealed that the United States now possessed "a new weapon of unusual destructive force." Stalin showed no interest, at least so it seemed to the president. ${ }^{38}$ But Stalin was not fooled. Through the Soviet spies planted in the Manhattan Project, Stalin was aware that the United States was about to explode the first atomic bomb. Truman's half-truth must have provoked Stalin's suspicion. ${ }^{39}$

Something must have changed in Stalin's thinking after Truman's less-than-truthful revelation about the atomic bomb. After receiving Ambassador Sato's clarifications about the Konoe mission on July 25, Deputy Foreign Commissar Lozovskii sent his recommendations as to how to respond to Japan's latest peace overtures. He suggested that the Soviet government continue to use stalling tactics by requesting the specific proposals that Konoe would bring to Moscow. Molotov flatly rejected this recommendation, writing in the margin of Lozovskii's dispatch "Not necessary [Ne to]." The time to fool Japan was over. All efforts now had to be concentrated on waging a war against Japan. ${ }^{40}$

\section{Potsdam proclamation}

Truman's half-truth about the atomic bomb piqued Stalin's suspicion, but an even greater shock was waiting for him. Contrary to Stalin's expectations, Truman was no longer interested in bringing Stalin into the joint ultimatum. Truman and Byrnes had been engaged in revising the draft proclamation they had received from Stimson on July 2 , and in this revision they had been consulting with the British in strict secrecy behind the backs of the Soviet delegation. ${ }^{41}$ They deleted the passage that Stimson had recommended in his original draft that would have allowed the possibility of Japan's 
retaining the monarchical system under the present dynasty. Truman and Byrnes also crossed out all references to the Soviet participation in the war that had been included in Stimson's original draft.

At 7 p.m. Potsdam time on July 26, the Potsdam Proclamation was given to the press to be released. At 4 p.m. Washington time American West-Coast shortwave radio stations began transmitting the text to Japan. After the press release, Byrnes sent a copy of the ultimatum to Molotov as a "diplomatic courtesy". Caught by surprise, Molotov immediately asked Byrnes to postpone the announcement for two or three days, but Byrnes told Molotov that it was too late, since the proclamation had already been handed to the press. ${ }^{42}$

We now know that the Soviets had prepared their own version of the Potsdam Proclamation. The Soviet draft began: "The time has come when the Governments of the Allied democratic countries - the United States, China, Great Britain, and the Soviet Union - have recognized that it is essential to make a joint declaration about our relations with Japan." It then listed Japan's transgressions, from its attack on China to its "treacherous" attack on Pearl Harbor, "the same perfidious surprise attack by which it had attacked Russia forty years ago." The draft stated: "People all over the world have a burning desire to terminate the continuing war. The United States, China, Great Britain, and the Soviet Union consider it their duty to take joint, decisive measures immediately to bring the war to an end." Finally, the document called on Japan to "lay down arms and surrender without any conditions." ${ }^{43}$

The document reveals the Soviet approach to the joint ultimatum. It is striking in its conciliatory tone towards the Allies, indicating how desperately Stalin wished to issue a joint declaration against Japan with the United States and Britain. But was Stalin not concerned that the issuance of such a joint declaration might immediately lead to Japan's surrender, thereby circumventing his ultimate objective of actually waging war against Japan to earn the trophies promised at Yalta? To avoid this undesirable outcome, the Soviet draft included a call for "unconditional surrender." The Soviet government was fully aware that the inclusion of this demand would lead Japan to continue the war, thus guaranteeing the prolongation of the war until the Soviet attack. Stalin and Molotov must have hoped that the issuance of the ultimatum might be postponed to coincide with the Soviet offensive. This expectation was by no means far-fetched, given that the Operation Division of the U.S. War Department had originally envisaged the optimal timing of the ultimatum as the moment of Soviet entry into the war. ${ }^{44}$

When Byrnes met Molotov on July 27, the Secretary explained that he had not received Molotov's request for postponement of the ultimatum until that morning. This was a flat lie, since Molotov through his interpreter had made this request as soon as he received the text on the evening of July 26 . On July 29 , Stalin proposed that the United States and Britain extend their formal request to Stalin to append his signature to the joint ultimatum. This request placed Truman and Byrnes in an awkward position. Byrnes wrote: "We had, of course, begun to hope that a Japanese surrender might be imminent and we did not want to urge the Russians to enter the war." But they could not ignore Stalin's request. In the end, the United States made a tortuous argument that the Soviet Union could declare war against Japan on the basis of Paragraph 5 of the Moscow Declaration of October 30, 1943, as well as the United Nations Charter Articles 103 and 106. ${ }^{45}$ Obviously, this was a flimsy legal basis, since the Moscow Declaration was signed only by three states, and the United Nations Charter had not been ratified. Japan had 
nothing to do with these documents. The main point of all this was that the United States rejected Stalin's request to extend a formal invitation to the Soviet Union to join the war against Japan. ${ }^{46}$ Byrnes wrote:

I must frankly admit that in view of what we knew of Soviet actions in eastern Germany and the violations of the Yalta agreements in Poland, Rumania and Bulgaria, I would have been satisfied had the Russians determined not to enter the war. Notwithstanding Japan's persistent refusal to surrender unconditionally, I believed the atomic bomb would be successful and would force the Japanese to accept surrender on our terms. ${ }^{47}$

The "timetable" that Truman and Byrnes had worked out became clear. Truman's intention was to gain Japan's surrender with the atomic bomb before the Soviet entry, and Stalin's objective was to enter the war before Japan's surrender. It was, indeed, a "race to the finish."

Stalin was fooled. He did not succeed in appending his signature to the joint ultimatum. But this failure reaped an unexpected benefit. The Japanese government noticed two things in the Potsdam ultimatum. First, Stalin did not sign the ultimatum, and second, the ultimatum contained the unconditional surrender demand without clarifying the position of the emperor. Prime Minister Suzuki Kantaro declared that he would "mokusatu" - ignore - the ultimatum. Japan would continue to seek Moscow's mediation to terminate the war. ${ }^{48}$

\section{Stalin's reaction to the Potsdam proclamation}

43 The fiasco of the Potsdam Proclamation convinced Stalin that Truman had decided to force Japan's surrender unilaterally before the Soviet entry into the war. His reaction was immediate. On July 30, he appointed Vasilevskii as supreme commander of the Soviet troops in the Far East as of August $1 .^{49}$ On August 2, Stavka ordered the formation of three fronts: the First Far Eastern Front under Marshal Kirill Meretskov, the Second Far Eastern Front under General Maksim Purkaev, and the Transbaikal Front under Marshal Rodion Malinovskii. The cloak of secrecy had been cast off. ${ }^{50}$

The Potsdam Conference was over on August 2, and the Soviet delegation left Berlin that day and returned to Moscow on August 5. On August 3, Chief of Staff Colonel-General S.P. Ivanov and "Colonel General Vasiliev: (Vasilevskii's nom de guerre) sent an important report on the situation of the front to Stalin and Antonov.

Vasilevskii first stated that the troops of the Transbaikal Front were completing the advance to the designated area of concentration about fifty to sixty kilometers from the border so that by the morning of August 5, they would be ready, "in accordance with your instructions." The report estimated that from the moment of receiving the order to cross the border to the actual beginning of action, "a minimum of five full days will be required." It then suggested that "the optimal time for the initiation of action" that was to say "crossing the border," would be "August 9-10." After the initial border crossing by the elite troops of the Transbaikal Front, the First and the Second Far Eastern Fronts should initiate action "on the same day and at the same time." In other words, contrary to the previous operationa plan, Vasilevskii proposed the attack in two waves, first by the border crossing by the elite troops of the Transbaikal Front, and then the simultaneous attacks by the First and the Second Far Eastern Fronts. Further it requested "no later than August 5 " the final instructions about the date of the beginning 
of the attack for the First and the Second Far Eastern Fronts as well as "about other related questions, especially of a "political and diplomatic nature." 51

This report suggests that the change of the date of attack from the previously agreed August 11 to August 9-10 was more than likely a response to a Stalin request to move up the date. Since this report was dispatched on August 3, Stalin's request must have been sent earlier than that date. It is most likely, although it cannot be determined from any available sources, that the order was issued from Potsdam on July 30, at the same time when Vasilevskii was officially appointed the commander of the Soviet Army in the Far East, after Truman rejected Stalin's last attempt to obtain the Western Allies' invitation to join the Potsdam ultimatum. Vasilevskii's request for instructions regarding questions of a "political and diplomatic nature" strongly suggests that the change of date was dictated by political motivations arising from the Potsdam ultimatum.

After receiving Vasilevskii's recommendation to advance the date of attack by one to two days, however, the Stavka seems to have turned down this request, presumably judging that to do so would be too risky. An element of surprise was a crucial component of the entire strategy, and all troops across the long border had to attack on the same day and at the same time. As previously agreed, the precise time of attack was set at midnight Chita time on August 11 (6 p.m. Moscow time on August 10)..$^{52}$

\section{The Americans drop the atomic bomb on Hiroshima}

Stalin returned to Moscow on the evening of August 5. His appointment log for August 5 shows that immediately after his arrival at the Kremlin, he frantically resumed activities, meeting his top advisers. ${ }^{53}$ Then the shocking news reached Moscow. The Americans had dropped the first atomic bomb on Hiroshima at 8:15 Hiroshima time (0:15 Moscow time) on August 6.

The news seems to have crushed Stalin. Pravda did not report anything about the atomic bomb on Hiroshima on August 7, and only on August 8 did it report Truman's statement on the atomic bomb in a lower column on page 4 without comment. ${ }^{54}$ Stalin's appointment log for his Kremlin office shows that he did not see anyone on August 6 in the Kremlin, although we do not know about possible meetings at his dacha. It is possible to assume that Stalin was devastated by the news, believing that the game was over, that Japan would surrender, and that the Americans had won..$^{55}$ On the afternoon of August 7, Molotov was at the airport to meet the Chinese delegation headed by T.V. Soong. He was in a dejected mood, and told Soong that Japan was on the verge of collapse. ${ }^{56}$ This represented the mood of the Soviet leadership after the Hiroshima bomb.

\section{Soviets declare war on Japan}

50 Contrary to Truman's expectations, however, the atomic bombing on Hiroshima did not immediately lead to Japan's decision to surrender. On August 7, one day after the atomic bomb was dropped on Hiroshima, Foreign Minister Togo sent another urgent telegram to seek an immediate appointment with Molotov to obtain Moscow's answer regarding the Konoe mission. ${ }^{57}$ This meant that despite the Hiroshima bomb, Japan continued to rely on Moscow's mediation. 
territories promised at Yalta. The Soviets, with 1.5 million men, converged on Manchuria from three directions with astonishing speed. The Soviet attack shocked the Japanese policymakers, who had pinned their last hope to end the war on Soviet mediation. The Supreme War Council, which had not been called even after the atomic bomb was dropped on Hiroshima, was immediately summoned after the Soviet invasion. Nevertheless, the Japanese government still remained divided between those who advocated immediate surrender with only one condition, i.e., the preservation of the emperor system [kokutai] and those who insisted on other conditions. The second atomic bomb was dropped on Nagasaki when the Supreme War Council was in the middle of heated discussion, but the second atomic bomb had no influence on the outcome of the discussion. Finally, it took the emperor's unprecedented intervention on behalf of accepting the terms specified in the Potsdam Proclamation, with the sole condition that the imperial prerogatives would not be touched. ${ }^{63}$

Cahiers du monde russe, $52 / 2-3 \mid 2011$ 

to deploy the $56^{\text {th }}$ Rifle Corps in cooperation with the Pacific Fleet to invade southern Sakhakin and capture the island by August $22 .{ }^{69}$ The Soviet units succeeded in seizing Maoka on August 19 in a confused battle, but the main objective was to capture Otomari. The landing units encountered a violent storm on the way from Maoka to Otomari, and it was not until August 26, four days later than Vasilevskii's plan, that the Soviet troops captured the port. Since southern Sakhalin was a part of the territory to be given to the Soviets in the Yalta Secret Agreement, the United States did not raise any objections. Japan's Imperial General Headquarters ordered the Japanese forces in Sakhalin to obey the ceasefire after the emperor's acceptance of surrender. If capturing southern Sakhalin was the main purpose, there was no reason for Soviet haste. The major goal of the Sakhalin landing, however, was to use Southern Sakhalin, only 40 kilometers from 
Hokkaido at the closest point, as a springboard from which to launch the Kuril and Hokkaido operations.

Although the Yalta secret agreement stipulated that the Kurils be handed over to the Soviets, the geographic limits of this volcanic archipelago stretching from Kamchatka to Hokkaido had not been precisely defined. When the military leaders discussed the zones of military operations at the Potsdam Conference, the entire Kurils, except for the northernmost four islands, were given to the American zone. The Americans, however, did not realize that the Soviets had also acquired the right to capture the Kurils since the Sea of Okhotsk was recognized as a Soviet operation zone. ${ }^{70}$

The emperor's acceptance of surrender on August 14 prompted Stalin to initiate the Kuril operation. On the morning of August 15 (still August 14 in Moscow), clearly in response to Stalin's order, Vasilevskii ordered Purkaev and Admiral I.S. Iumashev, commander of the Pacific Fleet, to occupy the northern parts of the Kurils without expecting any reinforcement from other fronts. Purkaev in turn told Major General A.R. Gnechko, commander of the Kamchatka Defense District: "Japan's capitulation is expected. Taking advantage of this favorable situation, seize Shimushu, Paramushiru, and Onekotan."71 Gnechko had to come up with detailed operational plans, organize landing ships, commandeer fishing trawlers, and other logistical tasks in only two days. Inevitably many mistakes were made, and they led to disastrous results during the attack on Shimushu. ${ }^{72}$

An interesting aspect of this order was that the islands to be seized included not only Shimushu and Paramushiru, but also Onekotan, which belonged to the American zone of operation. Without knowing how the United States would react to the Soviet Kuril operation, Stalin had to be cautious. By including Onekotan, he would be able to test the American reaction. If he met with opposition from the Americans, he would retreat. If not, he would expand operations in the central and southern Kurils.

The Kuril operations almost ended up in a fiasco. The battle of Shimushu was waged for four days from August 18 to August 21, although Gnechko was ordered to capture the island by the end of August 18. The lack of preparations, absence of a well-planned and well-coordinated strategy, shortage of ships, equipment, artillery, and weapons, and the numerical inferiority of his soldiers made it impossible for Gnechko's forces to complete the mission to occupy the island by the end of the day on August 18, as ordered. If the Soviets won despite all these weaknesses, it was because the Japanese Imperial General Headquarters, horrified by the specter of victory, in no uncertain terms, ordered the defending Japanese division to surrender. ${ }^{73}$

Meanwhile, Stalin also engaged in diplomatic maneuvers. On August 15 Truman sent General Order Number 1 to Stalin through Harriman. This order designated the Allied forces to which Japanese armed forces should surrender. On the next day, Stalin sent his reply through Harriman as well as Gromyko in Washington. He "principally" accepted the contents of General Order No. 1 with two revisions. The first was "to include in the region of surrender of Japanese armed forces to Soviet troops all the Kuril Islands [italics mine]." The second was to include the northern part of Hokkaido above the demarcation line running from Kushiro to Rumoi in a Soviet occupation zone. ${ }^{74}$

Stalin revealed his intentions even more clearly in his August 17 directive to General Kuz 'ma Derevianko, who was appointed Soviet military representative to General Douglas MacArthur's Allied headquarters in Manila. Stalin instructed Derevianko to present Soviet demands to include the Kurils and the northern part of Hokkaido in the Soviet 
occupation zone. In addition, Derevianko was to demand the creation of a Soviet occupation zone for stationing Soviet troops in Tokyo. ${ }^{75}$

On August 18, Truman sent a reply to Stalin's August 16 letter. He agreed "to modify General Order No. 1 to include all the Kurile Islands" in the Soviet occupation zone. While conceding this point, however, Truman requested that the United States be granted "air base rights for land and sea aircraft" on one of the islands, preferably in the central group "for military purposes and for commercial use." Truman drew a clear line between Hokkaido and the Kurils. Hokkaido was a part of Japan proper, and he was not going to let Stalin have it. Nevertheless, Truman and his advisers seem to have been concerned that not conceding "all the Kurils" might lead to Stalin's negating the entire Yalta secret agreement. ${ }^{76}$

Stalin's proposal to include northern Hokkaido in the Soviet occupation zone was not a diplomatic ploy. He was dead serious about capturing Hokkaido. It should be recalled that he had remained non-committal regarding Hokkaido, when the Politburo debated this issue on June 26-27. Shortly before he wrote his August 16 letter to Truman, he ordered Vasilevskii to implement the Hokkaido and southern Kuril operation. On August 18 Vasilevskii, in turn, ordered the commander of the First Far Eastern Front "to occupy the northern half of Hokkaido from Kushiro to Rumoi and the southern part of the Kuril Islands" by September 1. For this operation three divisions of the $87^{\text {th }}$ Rifle Corps would be deployed: two divisions for the Hokkaido operation, and one division for the southern Kuril operation. ${ }^{77}$

On August 20, however, after Stalin received Truman's August 18 telegram, Antonov sent Vasilevskii an order, telling him to instruct the commander of the First Far Eastern Front to prepare the operation for Hokkaido and the southern Kurils, but to initiate this operation only by special order of the Stavka and "prepare for an operation either for Hokkaido or for the southern Kuril islands."78

On August 21, Vasilevskii issued two directives to begin "immediately and no later than August 21" the embarkation of the $87^{\text {th }}$ Rifle Corps from the Sakhalin ports of Maoka, Otomari, and Toyohira for the capture of Hokkaido and the southern Kurils. The commanders of the First and Second Far Eastern Fronts, the Pacific Fleet, and the air force were ordered to be ready for airborne operations over Rumoi and to make the air base available by August 23 for the occupation of the northern part of Hokkaido. In addition, Iumashev was to send two marine divisions in two or three echelons to Hokkaido. Finally, Vasilevskii reminded all commanders that he would personally give the order to begin the landing operations for Hokkaido, and that preparations for this operation should be completed by August $23 .{ }^{79}$ The Soviet war machine was about to claw its way on to Hokkaido.

But by August 22 something had happened to change Stalin's mind. On August 22 Stalin sent a letter in response to Truman's August 18 letter. He accused Truman of demanding airbase rights on the Kurils, which he claimed as the inherent Soviet territory. The Yalta secret agreement contained no such provisions, and "demands of such a nature are usually laid before either a conquered state, or such an allied state which is in no position to defend with its means certain parts of its territory." In contrast to Stalin's conciliatory August 16 letter, this letter was striking in its angry tone. Was Stalin really angry or was this anger merely a diplomatic ploy? It was most likely both. He was not at all grateful for Truman's concessions on the Kurils, which he thought rightfully belonged to the Soviet Union, and he was offended by Truman's rejection of his proposal to have a 
slice of Hokkaido. ${ }^{80}$ But why did it take Stalin four full days to answer Truman's message? This delay might be related to the progress of military preparations, Soviet intelligence with regard to the American determination to protect Hokkaido, or to the advice of those who argued - Molotov, for instance - that the occupation of Hokkaido might jeopardize the Yalta terms. Stalin had not yet cancelled the Hokkaido operation, but he was retreating from it.

But this retreat meant that the Kurils now assumed center stage. It also sealed the fate of 640,000 Japanese prisoners of war captured by the Soviet forces. Since Stalin had counted on some portion of the population of Hokkaido to work in the Gulags of the Soviet Far East, he needed the POW labor force to make good his loss. The Soviet State Defense Committee (GKO) adopted the notorious resolution GKO 9898 to dragoon the Japanese POWs for hard labor. ${ }^{81}$ Approximately, ten percent would die in captivity.

The US policymakers discussed how to respond to Stalin's angry letter. Byrnes was in no mood to challenge Stalin over the Kurils. Navy Assistant Chief Charles Cooke, and Army Assistant Chief John Hull had two telephone conversations on August 23, and agreed that neither the Kurils nor the American airbase rights there were important enough to sacrifice the lives of American soldiers. ${ }^{82}$ The Kuril case was closed. The United States would not lift a finger when the Soviets seized the islands.

Truman was not happy with Stalin's angry August 22 message. He wrote a reply on August 25, but the message was not delivered to Stalin until August 27. We do not know why he wasted five days in responding to Stalin's letter. What we do know is that these five days were crucial for the Soviet southern Kuril operation. In his letter to Stalin Truman explained about his request for the landing rights on the Kurils, emphasizing that the Kurils were not Soviet territory, but Japanese territory, "disposition of which must be made at a peace settlement." ${ }^{83}$ Truman's strongly worded response must have confirmed Stalin's suspicion that the United States was backing away from the commitment made at Yalta, and it must have made him even more determined to seize all the islands before the official termination of the war.

Stalin realized, however, that his August 22 message might have backfired. Now it was necessary to back off. He sent his reply to Truman on August 30. He regretted that a "misunderstanding" had slipped into their correspondence. He agreed to grant the landing rights to the United States on one of the Kuril islands in emergency cases during the Allied occupation of Japan, and even grant an airfield for landing commercial planes. But in return, he expected the United States to provide an American airfield for Soviet commercial planes on one of the Aleutian Islands. Needless to say, there was no commercial airline in the Soviet Union at that time, so this was also a ploy. The timing of this response is also important. The three days between the two letters brought the Soviet operations further south in the Kurils.

Gnechko's forces in charge of occupying the northern and central Kurils managed to seize all the islands in the northern and the central Kurils up to Uruppu, encountering no resistance from the Japanese forces. ${ }^{84}$ As for the southern Kuril operation, on August 23, Vasilevskii ordered Iumashev to dispatch the main divisions of the $87^{\text {th }}$ Rifle Corps from Sakhalin to Kunashiri and Etorofu, avoiding Hokkaido. By September 1, the Soviet forces had occupied Etorofu.

76 The next day, on September 2 Japan formally signed the surrender documents on the battleship USS Missouri in Tokyo Bay. But the Soviet forces had not completed the occupation of the rest of the Kurils. Kunashiri was not captured until September 3. From 
there the Soviets proceeded to occupy Shikotan and the Habomai group, which historically, administratively, and geographically belonged to Japan, and should have been in the American occupation zone. The occupation of all the Kurils was not completed until September 5, three days after the Pacific War was officially over.

\section{Conclusion}

During World War II, Stalin was not only concerned with the survival of the Soviet Union, but also with capturing the territories that would guarantee its security from its potential enemies. At the Yalta Conference, Stalin scored a diplomatic victory by having Roosevelt and Churchill offer him prizes in exchange for Soviet participation in the war three months after the capitulation of Germany. But in order to gain these war trophies, he had to enter the war, and conclude an agreement with the Chinese confirming the Yalta conditions.

Thus, for Stalin, the major challenge was to prolong the war long enough for the Soviets to join it. A number of problems confronted him in pursing this policy. First, he had to justify the violation of the Neutrality Pact with Japan. In April 1945, Molotov renounced the Pact, but made it clear that the Pact would be in force until April 1946. It was necessary to "lull the Japanese to sleep," under the pretense of neutrality, while behind the cloak of neutrality, the Soviets rushed troops and equipment to the Far East to prepare for the war against Japan. The Soviet Union also exploited Japan's overtures to the Soviet Union to mediate for peace, first through the Hirota-Malik negotiations, and later through the proposal to send Prince Konoe to Moscow as the emperor's special envoy. Nevertheless, there still remained the major problem of waging war against Japan in violation of the Neutrality Pact. And the negotiations with the Chinese were deadlocked.

In order to resolve these two issues, Stalin expected Truman's support at the Potsdam Conference. By emphasizing that the Soviet pledge to enter the war remained firm, Stalin attempted to solicit Truman's help to put pressure on the intransigent Chinese. But most importantly, Stalin expected, as he had been promised by Hopkins in May that the United States and Britain would invite the Soviet Union to sign the joint ultimatum against Japan.

The first atomic explosion in New Mexico changed the American policy. Truman and Byrnes were now convinced that the Americans had acquired a weapon to force Japan's surrender before the Soviets entered the war. They encouraged the Chinese to stand firm to drag on the negotiations, and the American delegation at Potsdam totally excluded the Soviet Union from the deliberations of the Potsdam Proclamation. Truman's less than candid revelation about the atomic bomb piqued Stalin's suspicion, but the most decisive turning point for Soviet policy came when the United States announced the Potsdam Proclamation, without any prior notification to the Soviet delegation.

81 Stalin was now convinced that the United States was determined to secure Japan's surrender before the Soviets entered the war. Nevertheless, even Stalin could not convince the Stavka to change the carefully planned military operation against Japan, which was scheduled to commence on August 11 on all fronts. The US dropping of the atomic bomb on Hiroshima, however, shocked Stalin. He believed that the game was over. But the Japanese request to seek Soviet mediation immediately revived his hope. He changed the date of the attack by forty-eight hours to August 9, and had Molotov 
read the declaration of war one hour before the Soviet attack. Stalin succeeded in joining the war in the nick of time.

Japan's delay in accepting the Potsdam terms unconditionally gave the Soviets time to advance deep into Manchuria. The emperor's acceptance of unconditional surrender on August 14 triggered more intensive Soviet military operations. The Stavka sent airborne units to capture key Manchurian cities, including Port Arthur and Dairen. The HokkaidoKuril operation began hastily. Stalin initially wished to seize not only the Kurils, but also the northern half of Hokkaido, but Truman intervened firmly to prevent Stalin's huge appetite from going beyond the Yalta Agreement. In order to prevent the Soviets from obtaining a slice of Hokkaido, however, Truman had to sacrifice the Kurils, although he knew that the islands, or at least some of them, should belong to Japan.

Stalin managed to acquire much of what he wanted, although he did not gain an occupation zone either on Hokkaido or in Tokyo. In the process, however, he alienated the Japanese by seizing what the Japanese believed to be their own legitimate islands by violating the Neutrality Pact, especially when the Japanese were desperately seeking his mediation. Just as in Europe, Stalin's Far Eastern acquisitions made Soviet security precarious in the long run.

Stalin's approach to Japan was motivated by his geostrategic interests, pure and simple, and had little to do with Marxist-Leninist ideology. He pursued his goals ruthlessly employing Machiavellian manipulations. But so did Truman. Both were, to borrow the title of David Holloway's recent article, "jockeying for position in the postwar world." Truman's use of the atomic bomb was perceived by Stalin as a means to intimidate the Soviet Union, making subsequent Soviet policies more intransigent rather than more amenable. The atomic bombings on Hiroshima and Nagasaki were not the first salvo of the Cold War, as the revisionist historians claim, but contributed to the exacerbation of Soviet-American relations, preparing the ground for the transition from the Grand Alliance to the Cold War.

\section{NOTES}

1. See Tsuyoshi Hasegawa, Racing the Enemy: Stalin, Truman and the Surrender of Japan (Cambridge, MA: The Belknap Press of Harvard University Press, 2005); idem, Anto: Sutarin, Toruman to Nihonkofuku (Tokyo: Chuokoron shinsha, 2006); Tsuyoshi Hasegawa, "The Atomic Bombs and the Soviet Invasion: Which Was More Important in Japan's Decision to Surrender?"; idem, "The Soviet Factor in Ending the Pacific War: From the Neutrality Pact to Soviet Entry into the War in August 1945," and David Holloway, "Jockeying for Position in the Postwar World: Soviet Entry into the War with Japan in August 1945," in Tsuyoshi Hasegawa, ed., The End of the Pacific War: Reappraisals (Stanford: Stanford University Press, 2007); V.P. Safronov, Voina na Tikhom okeane (M.: MPPA BIMPA, 2007).

2. For the last two points, see Holloway, "Jockeying for Position in the Postwar World," 146-149. 
3. What role the atomic bombings and the Soviet entry into the war played in Japan's decision to surrender is beyond the scope of this article. For this, see the books and articles cited in note 1, especially Hasegawa, ed., The End of the Pacific War: Reappraisals.

4. Jonathan Haslam, The Soviet Union and the Threat from the East, 1933-41 (Pittsburgh: University of Pittsburgh Press, 1992).

5. See Hasegawa, Racing the Enemy, 11-14.

6. Ibid., 14-20. For bibliography of the Neutrality Pact, see ibid., notes 9, 10, 11.

7. For the Stalin-Eden conversation, see O.A. Rzheshevskii, "Vizit A. Idena v Moskvu v dekabre 1941 g., i peregovora s I.S. Stalinym i V.M. Molotovym: Iz arkhiva prezidenta RF," Novaia i noveishaia istoriia, no. 3: 105, 118; see also Dimitri Akulov, "Soviet Foreign Policy During the Second World War: Cooperation and Conflict with the Western Allies, 1941-1943," PhD dissertation, University of California at Santa Barbara, 2012.

8. Hasegawa, Racing the Enemy, 25. Aleksei Kirichenko, "Hakkutsu: KGB himitsu bunsho,"This Is Yomiuri, (December 1992): 236-243. For the Foreign Ministers Conference in Moscow and the Teheran Conference, see endnote 25 in Hasegawa, Racing the Enemy, 311-312; Akulov, "Soviet Foreign Policy During the Second World War."

9. Hasegawa, Racing the Enemy, 25-26. For Maiskii's report, see Document no. 5, "Zaniat 'sia podgotovkoi," Istochnik, no. 4 (1995): 124-125, 133-134; for Malik's report, see AVP RF (Arkhiv vneshnoi politiki Rossiiskoi Federatsii), f. 06, op. 6, pap. 58, d. 803a, 1. 204-258. See also Holloway's descriptions of the reports by Maiskii, Malik, and Lozovskii, Holloway, "Jockeying for Position in the Postwar World," 151-155.

10. Hasegawa, Racing the Enemy, 27. A. Vasilevskii, Delo vsei zhizni (M.: Izd-vo politicheskoi literatury, 1975), 552-553; Shtemenko, The Soviet General Staff at War, vol. 1, 406; S. Shtemenko, "Iz istorii razgroma Kvantunskoi armii," Voenno-istoricheskii zhurnal, no. 4 (1967): 55.

11. Hasegawa, Racing the Enemy, 32; "Conversation: MILEPOST," 14 Dec. 44, Harriman Papers, Moscow Files, 8-14 Dec. 44; Harriman to the President, 15 Dec. 44, Harriman Papers, Moscow Files, 15-20 Dec. 44, Library of Congress.

12. For the complete text of the Yalta Agreement, see Hasegawa, Racing the Enemy, 35; Holloway, "Jockeying for Position in the Postwar World," 156.

13. Hasegawa, Racing the Enemy, 35-36. Prior to the Yalta Conference, George Blakeslee recommended that Japan retain the southern Kurils, but that the northern and the central Kurils should be placed under Soviet trusteeship. Russian historian G.N. Sevost 'ianov claims that he found the Blakeslee memorandum in Russia's Presidential archive. If this information is correct, Stalin had access to the Yalta papers through his spy, possibly in the State Department. G.N. Sevost'ianov, "Iaponia $1945 \mathrm{~g}$. v otsenke sovetskikh diplomatov, novye arkhivnye materialy," Novaia i noveishaia istoriia, no. 5 (1995): 34. Sevost'ianov cites the archival source in the Presidential Archive, Arkhiv Prezidenta RF, f. 3, op. 66, d. 1061, 1. 15-18, but this archive is not accessible to most of researchers including Russian historians.

14. Hasegawa, Racing the Enemy, 46-47; "Priem Iaponskogo posla Sato," 4 April 45, Iz dnevnika V.I. Molotova, AVP RF, f. 06, op. 7, pap. 2, d. 30, 1. 32, f. Sekretariat V.M. Molotova, op. 7, por. 28, pap. 2, 1. 3; as for Sato's description of his meeting with Molotov, see Sato to Shigemitsu, Telegram No. 676, Gaimusho Gaiko shiryokan, Morita file (obtained from Morita Ryuji), 10-12. For the English translation from the Japanese, see SRH-071, Abrogation of the Soviet-Japanese Neutrality Pact: PSIS 400-8, 23 April 45, Records of 
National Security Agency/Central Security Service, Studies on Cryptography 1917-1972, Box 23, RG 457, NA. This is a summary based on the Magic Intercepts. Slavinskii also interprets, as I do, that Molotov was engaged in deception. B.N. Slavinskii, Pakt o neitralitete mezhdu SSSR i Iaponiei: diplomaticheskaia istoriia, 1941-1945 gg (M.: TOO, "Novina," 1995), 165-167. Kirill Cherevko, criticizing Slavinskii, justifies Molotov's explanation as perfectly legal. K.E. Cherevko, Serp i molot protiv samuraiskogo mecha (M.: Veche, 2003), 265-271. If one follows Cherevko's reasoning, however, had Japan violated the Neutrality Pact in June 1941 after the German attack on the USSR on the grounds that the situation had radically changed, this would also have been justified.

15. In January, Deputy Foreign Commissar Solomon Lozovskii had recommended that the government should renounce the Neutrality Pact before T.V. Soong's visit to Moscow, which was originally scheduled for the beginning of April. AVP RF f. 06, op. 7, pap. 55, d. 898, 1. 1-2; Slavinskii, Pakt, 261-263; Sevost'ianov, "Iaponia 1945 g.," 35-36.

16. Dnevnik Malika, 22 March 45; AVP RF, f. Molotova, op. 7, pap. 54, d. 891, 1. 201-202. Also see Document 195 (report of the Tokyo rezidentura) Velikaia otechestvennaia, vol. 7, pt. 1, 207-208. See also, Holloway, "Jockeying for Position in the Postwar World," 160-161.

17. Documents 312 and 313, Velikaia otechestvennaia, vol. 7, pt. 1, 330-332.

18. The best account of the Hopkins-Stalin conference is "Hopkins-Stalin Conference: Record of Conversations between Harry L. Hopkins and Marshal Stalin in Moscow," 26 May-6 June 1945, Papers of HST, Staff Members and Office File, Naval Aide to the President Files, 1945-1953, Subject File, Box 12, "Hopkins-Stalin Conference in Moscow," Harry S. Truman Library. These conversations are also contained in FRUS: Potsdam, vol. 1, 21-62, but the FRUS record is incomplete, lacking a portion of the fourth and the entire fifth conversations. For the Russian version, see Documents 258, 260, SovetskoAmerikanskie otnosheniia, vol. 2, 397-403, 404-411.

19. Document 260, Sovetsko-Amerikanskie otnosheniia, vol. 2, 406. The Russian version better conveys Stalin's talk than the American version. "Hopkins-Stalin Conference, Third Meeting," 3; FRUS: Potsdam, vol. 1, 43-44. The American version, however, makes it clear that it was Stalin, not Hopkins, who initially raised the question of unconditional surrender. Part of the conversation is omitted in the Russian version.

20. This remains my speculation. Documentary and archival evidence on the decision making process at the highest level is woefully lacking.

21. See "Hopkins-Stalin Conference, Third Meeting," 7; FRUS: Potsdam, vol. 1, 47. According to the American version, "Mr. Hopkins said he thought at the next meeting of the three heads of Government all these matters should be discussed." But the Russian version is more specific, stating: "Hopkins said that at the next meeting Marshal Stalin and Truman can discuss possible proposals for Japanese capitulation and also plans of occupation of Japan, and other urgent matters." Document 260, Sovetkso-Amerikanskie otnosheniia, vol. 2, 407.

22. Hasegawa, Racing the Enemy, 91-94. As for the Hirota-Malik meetings, see AVP RF, f. 0146, fond Referentura po Iaponii, op. 29, pap. 269, d. 4, 1. 262-265. For the abbreviated version of the conversation, see "Za kulisami Tikhookeanskoi bitvy," Vestnik MIDa SSSR, 15 Oct. 1990, 43-56. For the Japanese version, see Hakone Kaidanroku, Nihon gaimusho kiroku, Gaimusho ed., Gaiko shiryo: Nisso gaiko kosho kiroku no bu (Tokyo: Gaimusho, 1946), $148-154$, is merely a brief summary of the Malik-Hirota talks. Malik's diary in the Russian Foreign Ministry archive is the most detailed account of the conversations. 
23. Shtemenko, Soviet General Staff at War, vol. 1, 423; Vasilevskii, Delo vsei zhizni, 563.

24. Izvestiia, July 28, 1992. This is based on retired Colonel D. Belorusov, then the Chief of Staff of the Transbaikal Front, who participated in the meeting. This account is repeated in Slavinskii, Pakt, 305-306; B.N. Slavinskii, Sovetskaia okkupatsiia Kuril'skikh ostrovov (avgust-sentiabr' 1945 goda): dokumental'noe isledovanie (M.: TOO "Lotos," 1993), 126-127. See also Holloway, "Jockeying for Position in the Postwar World," 276, endnote 58, Holloway points out the discrepancies between Belorusov's account and Stalin's "visitor's log" (Istoricheskii arkhiv, no. 4 (1996): 105), from which neither Voznesenskii nor Meretskov were named. Holloway states: "That does not prove they were not there, of course, and the account of disagreements over landing on Hokkaido is plausible in view of what happened later, in August." In view of the significance of this meeting, it is hoped that the record of the meeting that must exist in the Presidential archive be made available.

25. Documents 314, 315, 316, Velikaia otechestvennaia, vol. 7, pt. 1, 332-336; also see three identical directives, no. 11112, 11113, 11114 in the Volkogonov Papers, reel 4, Library of Congress.

26. Hasegawa, Racing the Enemy, 116; Shtemenko, Soviet General Staff, vol. 1, 422, 423-424; Vasilevskii, Delo vsei zhizni, 564.

27. Hasegawa, Racing the Enemy, 120-126.

28. Vasilevskii, Delo vsei zhizni, 570. For the date of the attack, see Holloway, "Jockeying for Position in the Postwar World," 167-168.

29. See Odd Arne Westad, Cold War and Revolution: Soviet-American Rivalry and the Origins of the Chinese Civil War, 1944-1946 (New York: Columbia University Press, 1993), 32, 35.

30. Hasegawa, Racing the Enemy, 128-129; Holloway, "Jockeying for Position in the Postwar World," 165-167. For the minutes of the Stalin-Soong negotiations, see "Notes Taken at Sino-Soviet Conference, Moscow 1945 [hereafter Hoo Notes,] Victor Hoo Papers, Box 6, Hoover Institution; V.S. Miasnikov, ed., Russko-Sovetsko-Kitaiskie otnosheniia v XXveke: Dokumenty i materialy, 1937-1945; Book 2, 1945 g. (M.: Pamiatniki istoricheskoi mysli, 2000), 73-82, 105-111, 124-131, 134-137.

31. See Hasegawa, Racing the Enemy, chapter 4.

32. As for the differences between the Soviet and the American records of this meeting, see "Bohlen Notes," FRUS: Berlin, vol. 2, 43-46, and Berlinskaia (Potsdamskaia) konferentsiia rukovoditelei trekh soiuznykh derzhav - SSSR, SShA i Velikobritanii, 17 iulia-2 avgusta 1945 g: Sbornik dokumentov (M.: Izd-vo politicheskoi literatury, 1980), 43. See Hasegawa, "Soviet Factor in Ending the Pacific War," 211-214.

33. Robert H. Farrell, Off the Records: The Private Papers of Harry S. Truman (New York: Harper and Row, 1980), 53. Truman Diary, 17 July 45, original, Papers of Harry S. Truman, PSF, Roosevelt, Eleanor (folder 2)-S, Box 322, Ross, Mr. and Mrs. Charles G., PSF-Personal, 17 July 45, Harry S. Truman Library. In his memoirs Truman wrote: "There were many reasons for my going to Potsdam, but the most urgent, to my mind, was to get from Stalin a personal reaffirmation of Russia's entry into the war against Japan, a matter where our military chiefs were most anxious to clinch. This I was able to get from Stalin in the very first days of the conference." Truman, Memoirs, Years of Decision (Garden City, NY: Doubleday, 1955), vol. 1, 411. For the interpretation that those passages prove that Truman welcomed the Soviet entry into the war, see David McCullough, Truman (New 
York: Simon \& Schuster, 1992), 419; Richard B. Frank, Downfall: The End of the Imperial Japanese Empire (New York: Random House, 1999), 243.

34. FRUS: Potsdam, vol. 2, 1585, 1586.

35. FRUS: Potsdam, vol. 2, p. 1584; Berlinskaia konferentsiia, 43.

36. FRUS: Potsdam, vol. 2, 1587-1588. See Hasegawa, Racing the Enemy, 142; Hasegawa, "Soviet Factor in Ending the Pacific War," 213. On July 21, the U.S.-British combined chiefs met with their Soviet counterparts for the first time. Leahy asked General Antonov to provide an outline of the Soviet plan of action against Japan. Antonov answered that the Soviets "would be ready to commence operations in the last half of August." The actual date would depend on the outcome of negotiations with the Chinese. Antonov was operating under the assumption that the Americans needed Soviet entry into the war, and for that reason, he expressed the wish that the Allies would exert pressure on the Chinese to come to an agreement with the Soviet Union. "Tripartite Military Meeting, Tuesday, July 24, 1945, 2:30 PM," FRUS: Potsdam, vol. 2, 345-346.

37. Truman wrote to his wife: "Believe Japs will fold before Russia comes in. I am sure they will when Manhattan appears over their homeland." Farrell, off the Record, 54. Also Byrnes told Churchill that he cabled to Soong and told him to keep firm on negotiations. Churchill concluded: "It is quite clear that the United States do not at the present time desire Russian participation in the war against Japan." Quoted in Holloway, “Jockeying for Position in the Postwar World," 172.

38. For more details, see Hasegawa, Racing the Enemy, Chapter 4.

39. According to Gromyko, when Stalin returned to his villa, he commented that with atomic monopoly the United States would force the Soviet Union to accept its plans regarding Europe. "Well, that's not going to happen," he stated, and cursed "in ripe language," Stalin then vowed to speed up Soviet production of the bomb. Gromyko, Memoirs (New York: Doubleday, 1989), 110. That Stalin immediately understood that Truman was talking about the atomic bomb is also confirmed by Georgii Zhukov and Molotov. G.K. Zhukov, Vospominaniia i razmyhshleniia, vol. 3 (M.: Novosti, 1992), 336; F. Chuev, Sto sorok besed s Molotovym (M.: Terra-Terra, 1991), 81. For the Soviet intelligence report on the Manhattan Project, see Holloway, "Jockeying for Position in the Postwar World," 167. An important question that should be further investigated is: to what extent the American atomic bomb entered Stalin's calculations of strategy toward the war against Japan. How soon did Stalin believe the Americans were going to use the atomic bomb against Japan? If one takes into consideration that Soviet intelligence misjudged the timing of the Alamogordo test, it is more likely that Stalin did not have the information that the Americans were so close to using the atomic bomb. Holloway argues: "There is no clear evidence that Stalin expected the bomb to be used against Japan." See Holloway, "Jockeying for Position in the Postwar World," 167-170.

40. Slavinskii, Pakt, 293.

41. Proposal by the British Delegation, No. 1245," FRUS: Potsdam, vol. 2, 1277; Document 221, "Minutes from Mr. Eden to Mr. Churchill," 21 July 45, Rohan Butler and M.E. Pelly, eds., Documents on British Policy Overseas, series I, vol. 1, The Conference at Potsdam, JulyAugust 1945 [DBPO] (London: Her Majesty's Stationery Office, 1984), 514; Document 231,"Minutes from Mr. Rowan to Sir E. Bridges," 23 July 45, DBPO, 550-551; Eden to Churchill, P.M./45/S.T. July 21, 1945; Fouls to Bennett, July 24, 1945, F4065; Target No. 95, July 26, 1945, Policy for Post-War Control of Japan, July 25, 1945, F4605/364/G23, July 25; 
From Foreign Office to Washington, No. 7945, July 29, 1945, F4396/364/G, British National Archive, Kew Garden.

42. Ayers to Ross, Washington, 27 July 25, FRUS: Potsdam, vol. 2, 1290. James F. Byrnes, Speaking Frankly (New York: Harper, 1947), 207; Walter Brown Diary, 26 July Folder 602, James F. Byrnes Papers, Clemson University. No original copy of the Potsdam Proclamation was kept. The copy that was kept at the Byrnes Papers at Clemson University has Truman's signature, but Churchill's and Chiang Kai-shek's signatures were handwritten by Truman. "Atomic Bomb 1945, Proclamation by the Heads of Government," Folder 596 (1), James F. Byrnes Papers. Also see Robert H. Ferrell, ed., Truman in the White House: The Diary of Eben A. Ayers (Columbia: University of Missouri Press, 1991), 55.

43. AVP RF, f. 0639, op. 1, d. 77, 1. 9. This document was first introduced by Viacheslav P. Safronov, SSSR, SShA i Iaponiia: aggressiia na Dal'nem vostoke i Tikhom Okeane, 1931-1945 gg. . (M.: Institut Rossiiskoi istorii, 2001), 331-332. For its full translation, see Holloway, "Jockeying for Position in the Postwar World," 173.

44. Hasegawa, Racing the Enemy, 110-115. For further references on this issue, ibid, 327-328, endnotes $51,52,53,54,55,56$, and 58.

45. Paragraph 4 of the Moscow Declaration and Article 106 of the United Nations Charter stipulated that the four Allied nations would consult one another and take "joint action" on behalf of the community of nations. Article 103 stated that if there was a conflict between the obligations of the members of the United Nations and their obligations under any international agreement, their obligations to the United Nations Charter should take precedence. Truman-Molotov meeting 29 July 45; FRUS: Potsdam, vol. 2, 476; Byrnes, Speaking Frankly, 207-208; J.F. Byrnes, All in One Lifetime (New York: Harper, 1958), 297-298; Leahy Diary, 29 July 45, p. 133; Robert J.C. Butow, Japan's Decision to Surrender (Stanford University Press, 1954), 156-157. Molotov's request for the Allied invitation to the Soviet government to join the war is excluded from the Soviet version of the minutes of the Potsdam Conference, see Berlinskaia konferentsiia, 234-243.

46. Truman explained his refusal to accept Stalin's request: "I was not willing to let Russia reap the fruits of a long and bitter and gallant effort in which she had had no part." Truman, Memoirs, vol. 1, 402-404.

47. Byrnes, Speaking Frankly, 208.

48. See Hasegawa, Racing the Enemy, 165-170.

49. Doc. 318, Velikaia otechestvennaia, vol. 7, pt. 1, 336; Stalin/Antonov Order No. 11120, Volkogonov Papers, microfilm, reel 5, Library of Congress.

50. Doc. 320, Velikaia otechestvennaia, vol. 7, pt. 1, p. 337; no. 11121 in the Volkogonov Papers, reel 4, Library of Congress. These two orders appointed Meretskov and Purkaev. When Malinovskii was officially appointed as the commander of the Transbaikal Front cannot be ascertained.

51. Document 321, Velikaia otechestvennaia, vol. 7; pt. 1, 337-338.

52. Document 325, Velikaia otechestvennaia, vol. 7, pt. 1, p. 341; Shtemenko, "Iz istorii razgroma Kvantunskoi armii," Voenno-istoricheskii zhurnal, no. 5 (1967): 54. For a different interpretation of this order, see Holloway, "Jockeying for Position in the Postwar World," 167. 
53. Stalin's appointment book for August 5, 1945, RGASPI, (Rossiiskii gosudarstvennyi arkhiv sotsial'no-politicheskoi istorii), f. 558, op. 1, d. 416, 1. 66ob-67.

54. Pravda, August 7 and 8, 1945.

55. Holloway dismisses this view. He argues that Stalin's visitors' book does not necessarily accurately reflect his visitors, since he often conducted his business at his dacha. Oleg Khlevniuk also endorses his view that absence of any specific entry does not mean that a meeting did not happen, as little information is available on visitors to Stalin's dachas. Oleg Khlevniuk, "Stalin at War. Sources and its Interpretation," paper presented at the conference, "The Soviet Union and World War II," (Paris, May 2011) and published in this issue. Holloway cites Stalin's daughter Sevtlana Alliluyeva's memoirs. Svetlana writes that Stalin was preoccupied on the day after the bombing of Hiroshima. When she went to her father's dacha that day, she found that "he had his usual visitors. They told him that the Americans had dropped the first atomic bomb over Japan. Everyone was busy with that, and my father paid hardly any attention to me." Svetlana Alliluyeva, Twenty Letters to a Friend (Harmondsworth, UL: Penguin Books, 1968), 164; Holloway, "Jockeying for Position in the Postwar World," 176. Holloway states: "It is not clear whether this means August 6 or 7." Whether it was August 6 or 7 makes a huge difference. I contend that her descriptions are a better fit with the circumstances for August 7, after Stalin learned that Japan had not surrendered despite the atomic bombing on Hiroshima. How Stalin reacted to the news of the Hiroshima bomb cannot be ascertained until further archival materials become available.

56. Memorandum of conversation between Harriman and Molotov, Aug. 7, 1945, Harriman Papers, Moscow Files, 5-9 Aug. 45, Library of Congress.

57. Togo to Sato, 7 Aug. 45, in Shusen shiroku, vol. 4, 77; Sato to Togo, 7 Aug. 45, Shusen shiroku, vol. 4, 77-78.

58. Documents 325, 326, 327, and 328, Velikaia otechestvennaia, vol. 7, pt. 1, 341-343.

59. For the detailed minutes of negotiations, see Hoo Notes, 7 Aug. 45, 41-56; Victor Hoo Papers, Box 6, Hoover Institution Archive, and Document 693, Russko-Sovetsko-Kitaiskie otnosheniia, 156-181.

60. For Sato's meeting with Molotov, see “Priem Posla Iaponii Naotake Sato v 17 chas 00 min, 8 avgusta 1945 g.," "Ob ob"iavlenii voiny Iaponii SSSR," Iz dnevnika V.I. Molotova, AVP RF, f. Molotova, op. 7, por., No. 924, pap. 55, 1. 1-7; Sato, Kaiso 80-nen, 498-500; Gaimusho, ed. Gaigo shiryo: Nisso gaiko kosho kiroku no bu, 162-163.

61. Truman, Memoirs, vol. 1, 425; "Declaration of War on Japan by the Soviet Union," Harriman Papers, Moscow Files, 5-9 Aug. 45, Library of Congress.

62. "Declaration of War on Japan by the Soviet Union," Harriman Papers, Moscow Files, 5-9 Aug. 45, Library of Congress.

63. For the Japanese decision to surrender and how the atomic bombings and the Soviet entry into the war played in the decision, see endnote 1 of this chapter, especially, Hasegawa, Racing the Enemy, chapter 5, and Hasegawa, "The Atomic bombs and the Soviet Invasion: Which Was More Important in Japan's Decision to Surrender," in Hasegawa, ed., The End of the Pacific War: Reappraisals.

64. Hasegawa, Racing the Enemy, 217-222.

65. Ibid., 239; Westad, Cold War and Revolution, 52-53; Documents No. 708, 711, RusskoSovetsko-Kitaiskie otnosheniia, 182, 184; Hoo Notes, 70-74. 
66. Hasegawa, Racing the Enemy, chapters 5 and 6.

67. Krasnoznamennyi dal'nevostochnyi: istoriia krasnoznamennogo Dal'nevostochnogo voennogo okruga (M., Voennoe izdatel'stvo, 1985), 221.

68. Document 343 and Document 353, Velikaia otechestvennaia, vol. 7, pt. 1, 355-356.

69. Nakayama Takashi, 1945nen natsu: saigono nissosen (Tokyo: Kokusho kankokai, 1995), 102, 104, 113, 143-149; David M. Glantz, Soviet Operational and Tactical Combat in Manchuria, August Storm (London: Frank Cass, 2003), 250-252, 267-269; Kranoznamennyi dal 'nevostochnyi, 230-234.

70. "Meetings of the United States and Soviet Chiefs of Staff, Thursday, July 26, 3 p.m.," FRUS: Potsdam, vol. 2, 273-274. For U.S. policy towards the Kurils, see Hasegawa, Racing the Enemy, 264-267.

71. Slavinskii, Sovetskaia okkupatsiia, 73-81; No. 10542, 15 Aug. 45, MO TsVMA (Ministerstvo oborony Tsentral'nyi voenno-morskoi arkhiv), f. 129, d. 26770, 1. 119; Document No. 402, Velikaia otechestvennaia, vol. 7, pt. 2, 24.

72. Sakhalinskii kraevedcheskii arkhiv, f. Gnechko, Zhurnal boevykh deistvii voisk Kamchatskogo oboronitel'nogo raiona po ovladeniiu ostovami severnoi chasti Kuril'skoi griady $v$ period 15-31.8-1945 g (hereafter Gnechko, Zhurnal), 1-3, 9-11. Slavinskii, Sovetskaia okkupatsiia, 87. Slavinskii uses the archival material, "Otchetnye dokumenty po zakhvatu Kuril'skoi griady," MO TsVMA, f. 129, d. 26770. This seems to be identical with Gnechko's report in the Sakhalin archive. Also see somewhat unreliable, Glantz, Soviet Operational and Tactical Combat in Manchuria, 286-293.

73. For the battle of Shimushu, see Slavinskii, Sovetskaia okkupatsiia, 91-103; Nakayama, 1945nen natsu, 180-220; John Stephan, Kuril Islands: Russo-Japanese Frontier in the Pacific (Oxford: Clarendon Press, 1974), 158-164; V.N. Bogrov, Iuzhno-Sakhalinskaia i Kuril'skaia operatsii (Avgust 1941 goda) (M.: Voennoe izdatel'stvo, 1959), 82-101; Gnechko, Zhurnal, 13-29; "Otchetnye dokumenty po zakhvatu Kuril'skoi griady"; Document 403, Velikaia otechestvennaia, vol. 7, pt. 2, 23-32; Tsutsumi Husaki, "Kitachishima heidan no shusen" (typewritten manuscript, B œisho b œi kenkyujo, Military History Division); also see interviews with Takuma Risaburo and Kawada Kyushiro, Hoppogun, Dai5 homengun kankei choshuroku (Bœisho Bœi kenkyujo, Military History Division). See, an excellent article, Itani Yutaka, "Shimushu To: 1945nen 8 gatsu," Kyokai Kenkyu, 2 (2011): 31-64.

74. Document No. 363, Ministerstvo inostrannykh del SSSR, Perepiska predsedatelia soveta ministrov SSSR $s$ prezidentami SShA i prem'era ministrami Velikobritanii vo vremia Velikoi Otechestvennoi Voiny, 1941-1945 gg [hereafter Perepiska] (M.: Gosudarstvennoe izdatel'stvo politicheskoi literatury, 1957), vol. 2, 263-264; RGASPI, f. 558, op. 1, d. 372, 1. 95-108; Stalin to Truman, transl. and the Russian original, Papers of Harry S. Truman, Files of the White House Naval Aide, Harry S. Truman Library; ABC, Japan 387 (15 Feb. 45), Sec. 4, Box 506, RG 165, National Archive. For Stalin's telegram to Gromyko containing his answer to Truman and the draft with the handwritten revision, see RGASPI, f. 558, op. 1, d. 372, 1. 109-110.

75. Document 633, Velikaia otechestvennaia, vol. 7, pt. 7, p. 259-260.

76. Truman to Stalin, 17 Aug. 45, Truman Papers, Files of the White House Naval Aide, Harry S. Truman Library; also ABC, Japan 387 (15 Feb. 45), Box 506, RG 165, National Archive; Document 364, Perepiska, vol. 2, 264. Actually the first draft of Truman's reply included only his agreement to include all the Kurils in the Soviet occupation zone. Only in the second draft was the request for airbase rights added. ABC, Japan 387, (15 Fe. 45), 
Se. 1-B, RG 165, National Archive. It should be pointed out that Stalin's August 17 letter had sobering effects on U.S. occupation policy toward China and Korea. The U.S. intended to send troops to Dairen, but it conceded Dairen to the Soviets, but the U.S. was determined to send naval ships to a Korean port to protect the occupation zone south of the $38^{\text {th }}$ parallel. Ironically, the Soviets were determined to take Dairen, but had no intention to cross the $38^{\text {th }}$ parallel.

77. Telegram 14/III from Vasilevskii and Trotsenko to Meretskov, 18 Aug. 45, Volkogonov Papers, reel 4, Library of Congress; Document 405, Velikaia otechestvennaia, vol. 7, pt. 2, 36.

78. Antonov to Vasilevskii, No. 14653, Volkogonov Papers, reel 4, Library of Congress (italics added by me).

79. Vasilevskii's handwritten order, 21 Aug. 45, Volkogonov Papers, reel 4, Library of Congress; Voroshilov to Commanders of the First and Second Far Eastern Fronts, Pacific Fleet, Air Force, 21 Aug. 45, Vasilevskii and Trotsenko's order No. 20 (14726), 21 Aug. 45, "Zhurnal boevykh deistvii shtaba TOF, BFKP 5 'Skala,"' MO TsVMA, f. 17752, 1. 149-150; Staff of the Pacific Fleet to Commander of the $16^{\text {th }}$ Army, 21 Aug. 45, MO TsVKA, f. 79 (Sekretariat NKVMF), d. 38941.

80. Stalin to Truman, 22 Aug. 45, the English translation and the Russian original, Truman Papers, Files of the White House, Naval Aide, Harry S. Truman Library; Stalin to Truman, 22 Aug. 45, Harriman Papers, Moscow Files, 23-25 Aug. 45, Library of Congress; also Molotov to Gromyko, RGASPI, f. 558, op. 1, d. 372, 1. 111-112; Document 365, Perepiska, vol. 2, 265.

81. Viktor Karpov, Plenniki Stalina: Sibirskoe internirovanie Iaponskoi armii, 1945-1956 gg. (Kiev-L'vov, 1997), 36-37; E.L. Katasonova, Iaponskie voennoplennye v SSSR: bol'shaia igra velikikh derzhav (M.: Izdael'stvo Kraft, 2003), 34-39.

82. Telephone Conversation, Hull and Cooke, 1710, 23 Aug. 45, OPD, Executive File \#7, Item \#35a, Folder \#1, “Telephone conversations (6 Aug. 45-25 Aug. 45), RG 165; also OPD 336TS, \#126 Box 144, RG 165; Hull's memorandum for the Assistant Secretary of War, 24 Aug. 45, OPD 336TS, \#126, Box 144, RG 165, Telephone Conversation, Lincoln and Gerhard, 24 Aug. 45, all in National Archive. If Cooke and Hull had telephone conversations on Stalin's August 22 letter, they must also have discussed previous exchanges between Truman and Stalin. No archival sources are found on such conversations.

83. Personal message from the President to Generalissimo Stalin, Harriman Papers, Moscow Files, 24-27 Aug. 45, Library of Congress; Document 366, Perepiska, vol. 2, 265-266.

84. For Gnechko's northern Kuril operation, see Hasegawa, Racing the Enemy, 280-282; Gnechko, Zhurnal, 29-34; Slavinskii, Sovetskaia okkupatsiia, 106-108, 110-113.

\section{ABSTRACTS}

Abstract

This paper argues that Soviet policy during World War II in Europe was from the very beginning 
integrally connected with its policy toward the Far East. At the Yalta Conference, Stalin agreed to join the war three months after Germany surrendered in return for the war trophies promised by Franklin D. Roosevelt. In April, the Soviet government notified the Japanese government that it had no intention to renew the Neutrality Pact, but assured the Japanese that the pact would be in force until it expired in April 1946. Hiding behind the cloak of neutrality, the Soviet Union transported troops and equipment to the Far East in preparation for the war against Japan. In July, the Japanese government sought Moscow's mediation to terminate the war. Stalin took advantage of the Japanese request to prolong the war. Despite his expectations, however, Stalin was excluded from the Potsdam Declaration at the Potsdam Conference. The race began between Harry S. Truman, who wanted to force Japan to surrender with the atomic bomb, and Stalin, who intended to enter the war before Japan's surrender.

Résumé

La politique soviétique menée en Europe pendant la Seconde Guerre mondiale a toujours été en étroite corrélation avec celle pratiquée envers l'Extrême-Orient. C'est ce que l'article tend à démontrer. À la Conférence de Yalta, Stalin accepta d'entrer en guerre contre le Japon trois mois après la capitulation de l'Allemagne en échange des trophées de guerre promis par Franklin Roosevelt. En avril 1945, le gouvernement soviétique informa son homologue japonais qu'il n'avait pas l'intention de renouveler le Pacte de neutralité mais l'assura que le pacte resterait en vigueur jusqu'à son terme, soit en avril 1946. Se drapant dans le manteau de la neutralité, l'Union soviétique fit déplacer en Extrême-Orient des troupes et des équipements afin de préparer la guerre contre le Japon. En juillet, le gouvernement japonais rechercha la médiation de Moscou pour mettre un terme à la guerre. Stalin tira avantage de la requête des Japonais pour atermoyer. Cependant, contrairement à ses attentes, Stalin fut exclu de la Déclaration de Potsdam à la Conférence du même nom. La course s'engagea alors entre Harry Truman, qui menaçait le Japon de la bombe atomique s'il ne capitulait pas, et Stalin, qui souhaitait entrer en guerre avant que le Japon ne capitule.

\section{AUTHOR}

\section{TSUYOSHI HASEGAWA}

University of California at Santa BarbaraDepartment of History 